\title{
Impact of Fiscal Policy Instruments' Dynamics on Resource Sustainability in Nigeria
}

\author{
Ochalibe, A. I.*; Okoye, C. U. and Enete, A. A.
}

*Department of Agricultural Economics, Federal University of Agriculture Makurdi, Benue State - Nigeria

Email: alexee2007@yahoo.com Phone: +2348101342902

*Corresponding Author

\begin{abstract}
This research examined the impact of fiscal policy instruments on agricultural resources sustainability in Nigeria for the period 1980-2018. Specifically the study examined the causal relationship between fiscal policy instruments and resource sustainability; analyzed the instantaneous and compound growth rate of government expenditure, debt policy instruments and agricultural resources sustainability and; examined the impact of government expenditure and debt policy instrument on resource sustainability. Data were obtained from Central Bank of Nigeria (CBN) Statistics Data Base: and Food and Agriculture Organization Statistical data (FAOSTATS). From the findings, there exist a unidirectional relationship $(P<0.05)$ from government expenditure and debt to resource sustainability index. Government expenditure and debt instruments had instantaneous and compound growth rate $(P<0.05)$ of $7.62 \%, 7.92 \%$ and $1.23 \%$ and $1.24 \%$ respectively. The instantaneous growth rate for forest resources $(P<0.05)$, arable land $(P<0.05)$ and human capital $(P<0.05)$ were $-1.57 \%, 0.33 \%$ and $-1.93 \%$ with a compound rate of growth of $-1.58 \%, 0.34 \%$ and $-1.93 \%,-1.95 \%$ respectively. Government expenditure policy instruments yielded significantly $(P<0.05)$ positive impacts of $0.37 \%$ while increased debt profile significantly $(P<0.05)$ decreases sustainability index by $-0.27 \%$. Thus, fiscal policy instruments dynamics is essential for the attainment of inter-temporal efficiency of resources, hence sustainability. It was recommended that non-sustainable activities such as land degradation, deforestation and human capital depletion driven by unfavorable policies needs to be reappraised.
\end{abstract}

Keywords-Expenditure, debt, fiscal policy, resources and sustainability.

\section{INTRODUCTION}

Government activities are usually organized, directed and executed within the framework of policies. General policy instruments are classified into monetary and fiscal policies. Public expenditure is a good example of fiscal policy instrument that has variously been used in Nigeria government to sustain the economy. General policy instruments are tools that policy makers utilize to achieve their goal similar to pliers, spanners, and screw drivers in the hands of the mechanic. According to Blejer and Khan (1984) aggregate macroeconomic policy instruments covers government expenditure, debt and wage rate among others. Hussein (2005) described sustainability as non-declining natural capital. Sustainability of resources is necessary for the survival of humans, other organisms as well as agricultural growth. This is because agricultural growth revolves around resources and humans derive benefits from the natural resources and from properly- functioning ecosystems. Living sustainably can take many forms ranging from sustainable agriculture or using science to develop new technologies to policies objectives designed in a flexible and reversible manner that conserve natural resources (Hanley, Shogren and White 2007; Norton and Toman 1997).

However, policy makers face the challenge of creating the right incentives to optimize resource use from an economic, environmental and social perspective due to lack of concepts and methods for analyzing the environmental effect of policies. The environmental and social consequences of agricultural policies are also complex hence they are less frequently included in the national agricultural policies (Arene, 2016). These may have led to acute depletion of resources. For instance empirical studies on sustainability revealed that undisturbed areas which represent $46 \%$ of the earth's land surface and forests which covered about $50 \%$ of the earth's land area 8000 years ago, 
cover just about 30\% today (Mittermeier, Mittermeier, Gil, Pilgrim and Fonseca, 2003). Out of the 98.321 million hectares of land available in Nigeria, about $75.30 \%$ is considered as arable land, with $10 \%$ under forest reserves and the remaining $14.70 \%$ assumed to be made up of permanent pastures, built up areas and uncultivable waste (Olayemi, 1998). Yet, annual deforestation rate in Nigeria remained at the rate of $2.38 \%$ per year due to higher demand for agricultural land, fuel wood and rapidly growing population with land degradation caused by soil erosion (UNEP, 2011).

Furthermore the empirical and theoretical work of Munasinghe (1997) showed that policy instruments such as wage rate, exchange rate and trade liberalization policy contributed concurrently to economic, social and environmental sustainability. Munasinghe (1997) further opined that the application of policies for macroeconomic stability may result in unforeseen adverse short and longterm impacts on sustainability issues. Studies by Atkinson and Hamilton (2002) on sustainability indicators in Chile revealed that increased expenditures on education resulted in sustainability of resource stocks. Similarly, Munasinghe (1997) revealed that \$1 worth of educational expenditure yields a $\$ 1$ increase in human capital. United Nation (2008) revealed that intact natural resource suitable for supporting a diversity of plants and animals among others is a good measure of sustainability. Other things being equal, as population and waste grow, resource depletion is also likely to grow at a faster rate (Sloman and Wride, 2009). Economic theory also suggests that as more and more people crowd on to the fixed supply of world land, so diminishing returns to land will occur. While not denying a role of population growth or poverty, most case studies fail to confirm this simplification (Anderson, 1996; Rudel and Roper, 1996; Fairhead and Leach, 1996; Barraclough and Ghimire, 1996). Results of careful surveys of tropical deforestation support the view that population growth is never the sole and often not even the major underlying cause of forest-cover change (Angelsen and Kaimowitz, 1999; Geist and Lambin, 2001). However, deforestation is linked to changes in policies by national governments that pull and push migrants into sparsely occupied areas (Rudel and Roper, 1996). Mather and Needle (2000) reported that high rates of deforestation within a country are most commonly linked to population growth and poverty, shifting cultivation in large tracts of forests. Interestingly, government expenditure in human resource for accessible and quality education is required for skilful labour force while lack it may warrant depletion of skills and hence unsustainable development. Reduced government expenditure may also lead to depletion of resources e.g. logging (indiscriminate cutting down forest trees) especially in rural communities with its attendant consequences on resource sustainability. The simple reality that higher expenditure and growth in agriculture may warrant cutting down of trees (deforestation) if government intends to construct roads, dams, buildings etc, however should not be ignored.

There is an ongoing debate on the appropriate policy instruments in developing countries and Nigeria in particular however, empirical research on impact of policy instruments on agricultural resource sustainability is scanty with less emphasis on indirect policy outcomes. Most studies (e.g. Maskus, 1986; Ajayi 1995; Osagie, 1985 and Calvo and Reinhart, 2002 etc) focused on the concentrated on agricultural specific instruments e.g. agricultural subsidies, taxes and tariff, quotas, irrigation policies etc without looking at the effect of general policy instrument e.g. taxation, debt, general tariff level and aggregate expenditure. While studies (e.g. Abu and Usman, 2010; Fan and Rao, 2003) that attempt to address it from this perspective rather consider it from the narrow perspective without empirically examining drivers of resource sustainability and with little or no consideration of the fact that natural resource depletion has a cost to society and the economy as a whole and can distort national economy policy objectives. A review of past studies under the macroeconomic frame-work indicated a positive link between policy instruments that enhance public spending, agricultural growth as well as resource sustainability (Hartwich et al., 2010; Fan and Saurkar, 2008; Hanley, Shogren and White, 2007; Hanley and Atkinson, 2003). Fan and Rao (2003) showed that government spending on agriculture has provided a strong contribution to economic growth in Asia. Amassoma, Nwosa, and Ajisafe (2011); Abu and Usman (2010) showed that spending on rural infrastructure and productivity enhancing investments in agricultural export crops and livestock has the most promise for growth in income and food consumption in Africa. According to Obansa and Maduekwe (2013) agriculture remains the mainstay of the economy given its share in employment. Yet, in the majority of developing countries, public expenditure in agriculture is stagnant or declining, and this is reflected in poor contribution of agricultural outputs to GDP (Hartwich et al., 2010; World Bank, 2007; Olomola, 2007; Manyong et al., 2005). Still, most 
agricultural based economies depend on agriculture for a large share of their foreign exchange as exemplified by tobacco exports in Malawi and labor intensive nontraditional exports in Kenya and Senegal (World Bank, 2008).

\section{THEORY OF RESOURCE SUSTAINAB ILITY}

Following Hanley, et al. 2007 we consider an economy with representative agent who derives utility from consumption of both produced goods and environmental amenities, given by a vector $\mathrm{C}_{\mathrm{t}}$, where $\mathrm{t}$ indexes time. Production is determined by the aggregate (man-made + natural + human) capital stock, a vector $\mathrm{K}$, and technological progress which depends on solely the passage of time. An economy is deemed to be sustainable at time $t$ if utility is less than or equal to maximum sustainable utility at this time. Where sustainable here means consistent with non-declining value of utility over infinite time, at a constant discount rate $\mathrm{p}$ :

$\underbrace{\operatorname{Max}}_{c . k} \int_{0}^{\infty} U\left[C_{t}\right] e^{-p t} d t$

Pezzey and Toman show that for this economy to be sustainable, green net national product $Y^{t}$, defined by

$Y^{t}=\mathrm{P}(\mathrm{t}) \cdot \mathrm{C}(\mathrm{t})+\mathrm{V}(\mathrm{t}) \mathrm{K}(\mathrm{t})$

Where $\mathrm{K}$ is the rate of change in $\mathrm{K}$ per unit of time subject to production possibilities given by $\mathrm{K}(\mathrm{t})$ and $\mathrm{t}$ and where $\mathrm{P}$ is the relative price for the consumption goods and environmental amenities and $\mathrm{V}$ is the price for each element of the capital stock, must be non-declining at a time $\mathrm{t}$, that is

$\mathrm{Y}(\mathrm{t}) \leq 0 \Rightarrow \mathrm{U}(\mathrm{t})>U_{m}(t)$

That is if the green net national product is declining at a time $\mathrm{t}$, then utility must exceed the maximum sustainable level.

In equation (1) both the $\mathrm{K}$ and $\mathrm{C}$ terms are augmented, which means they include a value of time: this the discounted value of future exogenous technological improvements and resource price appreciation in a resource exporting country together with the capital gains on net foreign capital. The 'value of time' is shown in equation (2) but one can think of it intuitively as the discounted value of 'time passing' to the economy, in terms of its capital gains from both held overseas and from its natural resource net exports. Since consuming or utilizing more resources now than in the near future means attaching more utility to the present which implies discounting the future. It is therefore reasonable to argue that diminishing resources - forest, land and labour among other resources, in quantity and value simply is not sustainability but unsustainable development path.

\section{METHODOLOGY}

The study utilized secondary source of data. The study adopts a survey design. Information on arable land, forest area and agricultural land area were obtained from Food and Agriculture Organization Statistical data (FAOSTATS). Data on Government expenditures, and debt policy instrument were obtained from Central Bank of Nigeria (CBN) Statistical Data Base. Following the Joint UNECE/Eurostat/OECD Working Group of the UN on Statistics for Sustainable Development which was established in 2005 to identify good concepts and practices to assist national governments and international organizations in the design of sustainability indicator sets, three (3) resource sustainability indicators were considered among others. There are human capital resource, forest resource and arable land. These sustainability indicators cover both natural and human resources, by so doing the three predominant perspectives namely ecological, HartWick Solow and the Safe minimum approaches to sustainability were appropriately captured. Thus the index of sustainability was computed using the weighted average index as shown in Appendix 1. Data for the study were analyzed through the application of both descriptive and inferential statistical tools. Unit root test (ADF) was adopted as a pre-estimation technique. Objective I was achieved using Granger Causality; Objective II was achieved using Trend analysis and; Objective III was achieved through the use of dynamic regression model. After the estimation, a diagnostic test of misspecification, robustness/ heteroscedasticity, autocorrelation and multicollinearity were carried out to assess the validity of the empirical model.

\subsection{Unit Root Test -Augmented Dickey-Fuller (ADF) Model}

The Augmented Dickey-Fuller (ADF) test consists of estimating the following regression:

$\Delta y_{t}=x_{t}^{\prime} \beta+\delta y_{t-1}+\sum_{i=1}^{p} \Delta y_{t-p}+\varepsilon_{t}$

Where $\Delta=$ difference operator; $\mathrm{y}=$ vector of the $\mathrm{n}$ variables (i.e. interest rate, exchange rate, government expenditure, etc); $x=$ optional exogenous regressors which may consists of constant or a constant and trend; $p=$ number of lags; $\varepsilon_{t}=$ error term. Null hypothesis: $\mathrm{H}_{\mathrm{o}}: \delta=0$ (i.e., there is a unit root or the time series is non-stationary, or it has a stochastic trend).Alternative hypothesis: $\mathrm{H}_{1}: \delta<0$ (i.e., the 
time series is stationary, possibly around a deterministic trend). If the ADF statistic is greater than the critical value at $5 \%$ level of significance, that means the series is stationary, if the ADF statistic is less than the critical value at $5 \%$ level of significance, it means the series is nonstationary.

\subsection{Trend Analysis of sustainability Indicators over the \\ Period \\ Growth trend Model}

$\mathrm{Yt}=\mathrm{Y}_{0}(1+\mathrm{r}) \mathrm{t}$

Where $\mathrm{Y}_{\mathrm{t}}=$ rate of growth of sustainability indicators; $\mathrm{Y}_{0}=$ rate of sustainability indicators in a base year; $r=$ compound rate of growth of $\mathrm{Y} ; \mathrm{t}=$ time in chronological years in natural log form we have

$\operatorname{In} Y_{t}=\ln Y_{0}+\operatorname{tln}(1+r)$

Substituting $\operatorname{In} \mathrm{Y}_{0}$ with $\beta_{1}$ and $\operatorname{Ln}(1+\mathrm{r})$ with $\beta_{2}$, we re-write equation as

In $Y_{t}=\beta_{1}+\beta_{2} \mathrm{t}$

Adding the disturbance term to equation we obtain

$\operatorname{In} Y_{t}=\beta_{1}+\beta_{2} t+\mu t$

Equation (8) is a growth rate model developed for this study. A semi-log growth model was developed for this study instead of a linear trend model because the point of interest in this study is both absolute and relative change in the parameters of interest. The most important parameter in equation (8) is the coefficient $\beta 2$. This is the coefficient of the slope which measures the constant proportional or relative change in $\mathrm{Y}$ for a given absolute change in the value of the regressor, t. Multiplying $\beta 2$ by 100 gives the instantaneous growth rate at a point in time.

$\mathrm{IGR}=\beta_{2} \times 100$.

Where: IGR $=$ Instantaneous growth rate

According to Gujarati (2009) $\beta_{2}$ is the least-square estimate of the coefficient of the slope $\beta 2$, then taking the anti-log of $\beta_{2}$ and subtracting 1 from it and then multiplying the difference by 100 give the compound growth rate (CGR) over a period of time:

$\begin{array}{llllll}\mathrm{CGR} & = & {\left[\begin{array}{llll}\operatorname{antilog} & \beta_{2} & - & 1\end{array}\right] \quad \mathrm{x}} & 100\end{array}$ (10)

If the coefficient $\beta_{2}$ is positive and statistically significant or negative and statistically significant there is acceleration or deceleration in growth process respectively. If $\beta_{2}$ is not statistically significant there is stagnation in the growth process.

\subsection{Dynamic Regression Model}

Rsus $_{t i j}=\alpha+\sum_{i}^{j} \vartheta_{1}$ pcnstr $+\sum_{i}^{j} \vartheta_{2}$ pcnsrt $_{t-1}+\cdots+$

$\sum_{i}^{j} \vartheta_{q}$ pcnsrt $_{t-q}+v_{t} \ldots \ldots \ldots \ldots . . .(81)$

Where $t=q+1, \ldots, T$, InRsus $s_{t i j}=$ sustainability index of i- j resources namely land(arable), forest resource (forest) and human capital ( $\left.h \_c a p\right)$. $h \_c a p=$ human capital resource approximated by aggregate government expenditure on education per capita forest $=$ represents forest resource approximated by forest product per forest land area arable $=\quad$ arable land, measured as the productivity of agricultural land i.e. total agricultural output per hectare cstock $=$ total capital resource stock approximated by gross fixed capital formation in millions of current USD. pcnsrt $=$ fiscal policy instruments (government expenditure and debt) government expenditure (expn_agric) $=$ expenditure on agriculture measured as share of agriculture in the government expenditure outlay in millons of naira; debt instrument $($ debt $)=$ external debt measured as the external debt stocks, total (current US\$) to gross domestic product. It is the sum of public, publicly guaranteed, and private nonguaranteed long-term debt, short-term debt, and use of IMF credit; wage_rate= wage rate, control variable approximated by per capita income; pcnstr $_{t-1}=$ lag of policy instruments; $e_{t}=$ is a stochastic error term that satisfies the normal classical regression assumptions. It is expected that increased in public expenditures and wage rate will yield aggregate agricultural growth ceteris paribus.

\section{RESULT AND DISCUSSIONS}

\subsection{Pre-Estimation Test: Unit Root Test}

Table 4.1 reports the Unit root test results for Value Gross capital formation in current US (c_stock;) Arable land area and Permanent crops (1000ha) (arable); Forest products in million tonnes (forest_prd); Primary forest land area in 1000ha (forest_land); human capital (human_cap) proxied by education expenditure US\$) (expn_edu); Expenditure on Agriculture (current US\$) (expn_agric) 
Table 4.1: Results of aurgumented Dickfuller Unit root test

\begin{tabular}{|c|c|c|c|c|c|}
\hline Variable & ADF Statistics Z(t) & $\begin{array}{l}\text { Mackinnon } \\
\text { critical value@5\% }\end{array}$ & $\begin{array}{l}\text { differenced } \\
\text { level }\end{array}$ & $\begin{array}{l}\text { P-value } \\
Z(t)\end{array}$ & Remarks \\
\hline expn_agric & -2.503 & -1.688 & $1(0)$ & $0.008 * * *$ & Stationary \\
\hline$e x t \_d e b t$ & -3.668 & -1.688 & $1(1)$ & $0.001 * * *$ & Stationary \\
\hline Arable & -3.668 & -1.688 & $1(0)$ & $0.040 * *$ & Stationary \\
\hline human_cap & -1.342 & -1.688 & $1(1)$ & $0.094 *$ & Stationary \\
\hline forest_prd & -4.410 & -1.688 & $1(1)$ & $0.000 * * *$ & Stationary \\
\hline forest_land & 2.966 & -1.688 & $1(0)$ & $0.042 * *$ & Stationary \\
\hline c_stock & -2.664 & -1.688 & $1(0)$ & $0.006 * * *$ & Stationary \\
\hline
\end{tabular}

Note: $* * *$ significant at $1 \% ; \quad * *$ significant at $5 \%$ and $*$ significant at $10 \%$.

Source: Computed from secondary data, 2018

The results are summarized in the table 4.1. From the table, the variables government expenditure(expn_agric) $(\mathrm{P}=0.000<0.01)$; Arable land (Arable) $(\mathrm{P}=0.000<0.01)$; Forest land (forest_land) $(\mathrm{P}=0.000<0.05)$ and capital stock $\left(c_{-}\right.$stock $)(\mathrm{P}=0.000<0.01)$ were stationary at level while external debt (ext_debt) $(\mathrm{P}=0.000<0.01)$; human capital (human_cap) $(\mathrm{P}=0.000<0.01)$ and forest products (forest_prd) $(\mathrm{P}=0.000<0.01)$ were stationary at first difference order $\mathrm{I}(1)$. Therefore the null hypothesis of nonstationarity is rejected at $5 \%$ level of significance.

\subsection{Granger Causality Test between policy instruments and resource sustainability}

The result of the pair wise granger causality test between policy instruments and resource sustainability is presented in table 4.2.

Table 4.2 Granger pair wise causality test between policy instruments and resource sustainability

\begin{tabular}{lllll}
\hline Null Hypothesis & Df & Chi2-Statistics & Probability & Decision \\
\hline debt does not granger cause ndexstk & 3 & 30.426 & $0.000^{* * *}$ & Rejected \\
ndexstk does not granger cause debt & 3 & 4.008 & 0.261 & Not rejected \\
exp_agric does not granger cause ndexstk & 3 & 33.734 & $0.000^{* * *}$ & Rejected \\
ndexstk does not granger cause exp_agric & 3 & 4.144 & 0.246 & Not rejected \\
\hline
\end{tabular}

Source: Computed from secondary data, 2018

Note: $* * *$ significant at $1 \% ; * *$ significant at $5 \%$ and $*$ significant at $10 \%$.

The result of the causality test in table 4.2 revealed that at least a unidirectional causality exists between debt $(\mathrm{P}=0.000<0.01), \quad$ exp_agric $(\mathrm{P}=0.000<0.01) \quad$ and sustainability index (indexstk) $\quad(\mathrm{P}=0.000<0.01)$. This indicates that the government expenditure and debt policy instruments granger cause sustainability indicators in Nigeria. Therefore the null hypothesis should be rejected while the alternate hypothesis is not rejected. The implication is that fiscal policy instruments are relevant determinants of agricultural resource sustainability in Nigeria.

\subsection{Instantaneous and Compound Growth Rate of Policy Instruments and Sustainability Indicators}

The result from trend analysis of agriculture output (agrth); Expenditure on Agriculture (current US\$) (expn_agric);
Primary forest land area in 1000ha (forest_land); Arable land area and Permanent crops(1000ha)(arable); human capital (human_cap) proxied by education expenditure US\$) (expn_edu); and resource sustainability index(Rsus_index $)$ are presented in Table 4.3. From the table the trend of policy instrument showed that there was acceleration in the growth in fiscal policy instruments but deceleration in resource sustainability indicators with no recorded stagnation during the period under review. The result showed further that there was a deceleration in the index resource sustainability $(\mathrm{P}=0.068<0.1)$ during the period of study with instantaneous growth rate and compound growth rate of $-2.81 \%$ and $-2.84 \%$ respectively. However, there was a deceleration in the index of resource sustainability during the period of study with instantaneous growth rate and compound growth rate of $-2.81 \%$ and - 
$2.84 \%$ respectively. There was acceleration in growth for with instantaneous and compound growth rate of expenditure to agriculture $(\mathrm{P}=0.000<0.01)$, external debt
$(\mathrm{P}=0.082<0.1)$ with instantaneous and compound growth rate of $7.62 \%, 7.92 \% ; 1.23 \%, 1.24 \%$ respectively.

Table 4.3: Instantaneous and Compound Growth Rate

\begin{tabular}{|c|c|c|c|}
\hline & Instantaneous growth rate\% & Compound growth rate\% & P-value \\
\hline Agrth & 5.90 & 6.08 & $0.000 * * *$ \\
\hline Inexpn_agric & 7.62 & 7.92 & $0.000 * * *$ \\
\hline Inexdebt & 1.23 & 1.24 & $0.082 *$ \\
\hline forest_land & -1.57 & -1.58 & $0.008 * * *$ \\
\hline Arable & 0.33 & 3.38 & 0.470 \\
\hline human_cap & -1.93 & -1.95 & $0.005^{* * *}$ \\
\hline Rsus_index & -2.81 & -2.84 & $0.068 *$ \\
\hline
\end{tabular}

Source: Computed from secondary data, 2018

Note: *** significant at $1 \% ; \quad * *$ significant at $5 \%$ and $*$ significant at $10 \%$.

Although efforts were made through the use of monetary and fiscal policies to improve macro-economic stability and stimulate growth (Oluwatobi and Ogunrinola 2011) the growth rates were not sufficient enough to spur growth may well suggest failure of policy instruments application in this regard. The implication of the empirical results is that given the current pressure on natural resources the targets sets by the government of Nigeria may not be achievable since government has not utilized macroeconomic policy instruments such that revenue generation is increased through the productivity of resources to meet national objective for sustainability of available agricultural resources. The instantaneous growth rate for forest resources $(\mathrm{P}=0.008<0.01)$, arable land $(\mathrm{P}=0.47>0.01)$ and human capital $(\mathrm{P}=0.005<0.01)$ were $1.57 \%, 0.33 \%$ and $1.93 \%$ with a compound rate of growth of $-1.58 \%, 0.34 \%$ and $-1.95 \%$ respectively. This means that the relative change in forest resources, arable land and human capital with respect to absolute change in the trend variable were $1.57 \%, 0.333 \%$ and $1.93 \%$ respectively. Therefore there was a deceleration in forest resources and human capital while arable land was stagnant. These are clear indications that agricultural resources are not on sustainable path and more effort may be required to enhance sustainability of this resources however this cannot concluded without further analys is.

4.4 Impact of general policy instruments on index of resources sustainability

The result of the impact of government expenditure and debt policy instruments on resource sustainability is presented in Table 4.4 utilizing index of sustainability with useful insights. The result of finite distributed lag model considers the coefficient of the parameters as impact propensity. From the table, the intercept term has a coefficient of 2.4050 this implies that without policy instruments sustainability index will remain at $2.41 \%$. The $\mathrm{R}^{2}$ was 0.8528 . This means that $85.28 \%$ of the variation in sustainability index is accounted for by debt and government expenditure (expn). The F-statistics $(\mathrm{P}=0.000<0.01)$ was statistically significant at $1 \%$ indicating that all the variables included in the model jointly exert significant impact on agricultural growth.

Table 4.4: Results of Impact of fiscal policy instruments on index of resources sustainability

\begin{tabular}{lrrrr}
\hline Variables & B-Coefficient & Standard error & T-value & P-value \\
\hline Dependent & = Index of sustainability & & & $0.024^{* *}$ \\
Lndebt & -0.2745 & 0.1155 & -2.380 & $0.000^{* * *}$ \\
New_indexcstkL1. & 0.5907 & 0.1250 & 4.720 & $0.003^{* * *}$ \\
lnexpn L1. & 0.3688 & 0.1127 & 3.270 & $0.002^{* * *}$ \\
_cons & 2.4050 & 0.7119 & 3.380 & \\
Number of obs & $=$ & 37.0000 & & \\
\hline
\end{tabular}




\begin{tabular}{llr}
\hline $\mathrm{F}(5,31)$ & $=$ & 35.9100 \\
Prob $>\mathrm{F}$ & $=$ & 0.0000 \\
R-squared & $=$ & 0.8528 \\
Adj R-squared & $=$ & 0.8290 \\
Root MSE & $=$ & 0.1391 \\
\hline
\end{tabular}

Source: Computed from secondary data, 2018

Note: $* * *$ significant at $1 \% ; \quad * *$ significant at $5 \%$ and $*$ significant at $10 \%$.

The coefficient of government expenditure was 0.37d.p and statistically significant at $5 \%$. This means that a proportionate rise in government expenditure increased sustainability index by $0.37 \%$ ceteris paribus. This is in agreement with (NBS, 2016) who opined that for the 19902005 interval Nigeria lost $39.2 \%$ of its forest and woodland habitat tend to support this realization. The implication is that government expenditure in human resource for accessible and quality education is required for skillful labour force while lack it result in depletion of skills and hence unsustainable development. It also implies that poor policy instruments utilization may have discouraged sustainability of resources through low agricultural investment, over utilizing land, labour and other resources. Although higher expenditure may warrant cutting down of trees (deforestation) due to government interest in development through construction of roads dams, this result proved that government expenditure as policy instrument increased the sustainability of resources. It is pertinent to state that decrease in sustainability may not be unconnected with the conceptualization of this work too. Policy instruments targeted at growth in agriculture has the potential for increasing environmental damage resulting in unsustainable outcomes because agricultural growth relies on the world's natural resources to create wealth and share the need for infrastructures and both entails the risk of environmental damage however, this study is unable to establish this realization.

According to Hanley, Shogren and White, (2007) if natural capital turns out to be the binding constraint on output and stock of natural capital is allowed to decrease substantially, agricultural growth and sustainability will continue to decline and subsequently social welfare irreversibly diminished. Human capital development and dynamic agricultural innovation systems are critical to attract further investment in agriculture (Hueting, 2011). Therefore policies should support high-quality education and wellfunctioning extension services, innovative technology to restore forest resource and enhance human capital development and sustainability of other critical resources. The coefficient of debt (Indebt) was -0.27 and statistically significant at $10 \%$. This means that a proportionate rise in debt resulted in less than a proportionate change in sustainability index by $-0.27 \%$ ceteris paribus. The implication is that elasticity of debt with respect to sustainability index is inelastic. Consuming or utilizing more resources now than in the near future means attaching more utility to the present thereby discounting the future. Furthermore, to prefer benefits now and place a lower value on benefits received later is to "discount" future benefits" (Anderson, 2010). The results from Table 4.4 showed a statistical significant with F-statistics of $(\mathrm{P}=0.000<0.01)$ indicating that general policy instruments had impact on resource sustainability. Therefore the null hypothesis that says the impact of policy instruments on resource sustainability is not statistically significant is rejected at $1 \%$ significant level. The implication is that policy instruments have impact on resource sustainability.

Increased expenditure on agricultural sector is needed to purchase land, construct buildings, acquire machinery and equipment, and hire labour, carry out research and development etc (Obansa and Maduekwe, 2013). For instance improvements in water well drilling technology and submersible pumps, combined with the development of drip irrigation and low-pressure pivots, have made it possible to regularly achieve high crop yields (UN, 2008). According to Mohawesh, Yasser; Taimeh, Awni; Ziadat (2015) in the coming decades, cropland will continue to be lost to industrial and urban development and many tools will be called upon to offset these projections. In Europe, one such tool is a geo-spatial data system called SoilConsWeb (Shenoy and Kalagudi, 2012). Increased investments in sustainable agriculture and the use of favorable macroeconomic policy instruments are critical to the attainment of resource sustainability more so that unsustainable exploitation of resources on a large scale has led to massive negative effect on the environment and human capital (United, 2008). Expenditure in sustainable 
agriculture is needed in generating the necessary level of investment, both public and private, in technology and infrastructure to facilitate economic growth in Nigeria while and debt profile will retard growth. Therefore, Government policies that failed to utilize fiscal policy instruments correctly may deplete natural resource with negative consequences on agricultural growth and worsening poverty conditions of poor farmers as millions of them depend on agriculture for their subsistence (UNCTAD, 2016).

\section{CONCLUSION}

The findings revealed that resource sustainability index adjusted fairly to the dynamics of macroeconomic fiscal policy instruments in Nigeria. Unfavorable macroeconomic fiscal policy instruments such as increased debt and reduced expenditure on agriculture driven by increased demands for natural resources in Soil, Forest resources as well as Human capital depletion among others impacted negatively sustainability of resources. Government expenditure policy instruments yielded significantly $(\mathrm{P}<0.05)$ positive impacts of $0.37 \%$ while increased debt profile decreases sustainability index by $-0.27 \%$. The study brings to the fore the inter-connectedness that exist between macroeconomic policy instruments and sustainability of resources and the reality that agricultural growth revolves around services provided by the natural resource and humans derived benefits from these natural resources and from properly-functioning ecosystems is further deepened. The implication is that favorable policy instruments that strengthen inter- link between natural capital and agriculture will reduce poverty and raise development and sustainable resource management. It will allow agricultural investors to maximize returns on their investment by harnessing longterm economic benefits. Therefore, the attainment of macroeconomic goals required the use of fiscal policy instruments with possible positive impact on sustainability of agricultural resources. The study recommended that the rate of utilization of agricultural resources should equate or less their rate of replenishment and any critical thresholds they exhibited. Government should refrain from accumulating debt but rather increase government expenditure to education, investing in human capital development through budgetary allocations as well as intervention funds so as to secure future growth.

\section{REFERENCES}

[1] Abu, N. \& Usman, A. (2010). Government expenditure and economic growth in Nigeria, 1970-2008: A disaggregate analy sis. Business and Economics Journal, 1-18.

[2] Agu, S. Idike, A., Okwor, I. \& Ugwunta, D. (2014). Fiscal policy and economic growth in Nigeria: emphasis on various components of public expenditure. Singaporean Journal of Business Economics and Management Studies, 2(12), 37-57.

[3] Ajayi, S. I. (1995). Capital flight \& external debt in Nigeria. Research Paper 35, African Economic Research Consortium (AERC), Nairobi, Kenya.

[4] Amassoma, D., Nwosa, P. \& Ajisafe, R. (2011). Components of government spending and economic growth in Nigeria: An Error Correction Model. Journal of Economics and Sustainable Development, 2(4), 34-59.

[5] Anderson, L. E. (1996). The causes of deforestation in Brazilian Amazon. Journal of Environment and Development 5, 309-328.

[6] Andersen, P. P. \& Shimokawa, S. (2006). Rural infrastructure and agricultural development paper presented at the Annual Bank Conference on development economics, Tokyo, Japan, May 29-30, 2006.

[7] Angelsen, A. \& Kaimowitz, D. (1999). Rethinking the causes of deforestation: lessons from economic models. The World Bank Research Observer, 14, 73-98.

[8] Aregbeyen, O. (2017). Public expenditure and economic growth. African Journal of Economic Policy, 1(1)

[9] Arene, C. J. (2016). Economic Analysis of Agricultural and Rural Development Projects (Planning, Appraisal, Implementation, and Evaluation). $2^{\text {nd }}$ Edition. Enugu State: University of Nigeria Press.

[10] Atkinson, G. \& Hamilton, K. (2002) International trade and the ecological balance of Payments. Resource Policy, 28, 2737.

[11] Barraclough, S. L., Ghimire, K.B. (1996). Deforestation in Tanzania: Beyond simplistic generalizations. The Ecologist, 26 (3), 104-107.

[12] Blejer, M. I. \& Khan, M. S. (1984). Government policy and private investment in developing Countries. Intl. Monet. Fund Staff Papers, 31, 379-403.

[13] Calvo, G. \& Reinhart, C. (2002). Fear of floating. Quarterly Journal of Economics, 117(2), 379-408.

[14] Fairhead, J. \& Leach, M. (1996). Misreading the African Landscape: Society and Ecology in a Forest-Savanna Mosaic. Cambridge: Cambridge University Press.

[15] Fan, S. \& Rao, N. (2003). Public spending in developing countries: Trends, determination, and impact. EPTD Discussion Paper No 99, International Food Policy Research Institute, Washington, D.C.

[16] Fan, S., Yu, B. and Saurkar, A. (2008). Public spending in developing countries: Trends, composition, and changes. In Public Expenditure, Growth, and Poverty in Developing 
Countries: Issues, Methods, and Findings. Johns Hopkins University Press.

[17] FAO (2016). The state of food and agriculture: Climate change, Agriculture and Food security, Rome, Italy. http://www.fao.org/3/ publications

[18] Geist, H. J., Lambin, E. F. (2001). What drives tropical deforestation? A meta-analysis of proximate and underlying causes of deforestation based on sub-national scale case study evidence. LUCC Report Series No. 4. University of Louvain, Louvainla- Neuve.

[19] Hanley, N., Shogren J.F. and White, B. (2007). Environmental economics in theory and practice. New York, NY 10010. Palgrave Macmillan

[20] Hartwich, F., Kormawa, P., Ibrahim D. Bisallah, B., Odufote, B.O.\& Polycarp, I. M. (2010). Unleashing agricultural development In Nigeria through Value Chain Financing. Draft Report, September 2010. UNIDO; CBN and Bank of Industry, Nigeria.

[21] Hueting, R. (2011). The future of the environmentally sustainable national income: Okologisches Wirtschaften, 4(11), 30-35.

[22] Hussein, A. M. (2005). Principles of environmental economics: economics, ecology and public policy. New York, NY: Taylor \& Francis.

[23] Manyong, V. M., Ikpi, A., Olayemi, J. K., Yusuf, S. A., Omonona, B. T., Okoruwa, V. \& Idachaba F. S. (2005). Agriculture in Nigeria: Identifying opportunities for increased commercialization and investment. International Institute of Tropical Agriculture (IITA), Ibadan, Nigeria.

[24] Maskus, K. E. (1986). Exchange rate risks and U.S. trade: A sectoral analysis. Federal Reserve Bank of Kansas City. Econ. Rev.

[25] Mather, A. S. \& Needle, C. L. (2000). The relationships of population and forest trends. The Geographical Journal, 166 (1), 2-13.

[26] Mittermeier, R., Mittermeier, C. G., Gil, P.R., Pilgrim. J. \& Fonseca, G. (2003). Wilderness: Earth's Last Wild Places. Chicago University. Chicago Press.

[27] Mohawesh, Y. Taimeh, A. \&Ziadat, F. (2015). Effects of land use changes and soil conservation intervention on soil properties as indicators for land degradation under a

[28] Mediterranean climate" (PDF). Solid Earth, 6 (3), 857868. doi:10.5194/se-6-857. Munasinghe, M. (1997). Is environmental degradation an inevitable consequence of economic growth: tunneling through the environmental Kuznetsm curve. Ecological Economics. 29 (1999): 89-109
[29] Norton, R. D. (2012). Agricultural Development Policy: Concepts and Experiences. FAO Agricultural Policy Support Service -Policy Assistance Division. TCAS Working No.43.

[30] Obansa, S. A. J. and Maduekwe, I. M. (2013). Agriculture financing and economic growth in Nigeria. European Scientific Journal, (1), 1-37.

[31] Olayemi, J. K. (1998). Agricultural Development Strategy: Institutional framework and support. Paper presented at the workshop on Policy Issues and Planning in the Agricultural Sector, NCEMA, June 15-26, 1998.

[32] Olomola, A. S. (2007). Competitive Commercial Agriculture in Africa Study (CCAA): Nigeria Case Study. Final Report submitted to the Canadian International Development Agency (CIDA) and the World Bank.

[33] Oluwatobi, S. O. and Ogunrinola, I. O. (2011). Government expenditure on human capital development: Implications for economic growth in Nigeria, Journal of Sustainable

[34] Development, 4(3), $72-80$.

[35] Osagie, E. (1985). An operational econometric model of the Nigerian economy: Some preliminary estimates. Ife Social Science Review, 1(2), 149-165.

[36] Rudel, T. \& Roper, J. (1996). Regional patterns and historical trends in tropical deforestation, 1976-1990: A qualitative comparative analy sis. Ambio, 25, 160-166.

[37] Shenoy, V.V. \& Kalagudi, G.M. (2012) Enhancing plant phosphorus use efficiency for Sustainable cropping. Biotechnology Advances. 23(7-8),501-513. doi:10.1016/j.biotechadv.2005.01.004.

[38] Sloman, J. and Wride, A. (2009). Economics. Italy: Rotolito Lombarda United Nations Environmental Programme, UNEP (2011). Mainstreaming Environment and Sustainability into African Universities, MESA. Available at www.unep.org.25/08/11.

[39] United Nation (2008). Measuring Sustainable Development Report of The Joint Unece/Oecd/Eurostat Working Group on Statistics for Sustainable Development United Nations. New York and Geneva.

[40] UN Food Agricultural Organisation. (2001). FAO Statistical Databases. http://apps.fao.org

[41] World Bank (2008). An Assessment of the Investment Climate in Nigeria. World Bank. Washington D.C., USA.

[42] World Economic Forum, World Bank \& African Development Bank, WEF, WB, ADB, (2007). The Africa Competitiveness Report, Geneva: WEF.

[43] World Bank (2007). Nigeria-A fiscal agenda for change: Public expenditure management and Financial accountability review. Poverty Reduction and Economic Management, Africa Region, World Bank, Washington, D.C.

Appendix 1

Table 3.1 Index of Agricultural growth, human capital, Forest Arable land and capital stock

\begin{tabular}{rrrrrr}
\hline \multicolumn{1}{l}{ Year } & index_agrth & index_human & index_forest & index_Arable & \multicolumn{1}{c}{ Rsus_index } \\
\hline 1980 & 100.00 & 100.00 & 100.00 & 100.00 & 100.00
\end{tabular}




\begin{tabular}{|c|c|c|c|c|c|}
\hline 1981 & 109.24 & 119.77 & 97.20 & 109.24 & 108.74 \\
\hline 1982 & 102.60 & 82.82 & 100.41 & 102.60 & 95.28 \\
\hline 1983 & 99.30 & 62.73 & 99.49 & 99.30 & 87.17 \\
\hline 1984 & 95.62 & 71.61 & 100.10 & 95.62 & 89.11 \\
\hline 1985 & 118.56 & 89.12 & 99.85 & 113.56 & 100.84 \\
\hline 1986 & 109.37 & 60.45 & 99.95 & 100.11 & 86.84 \\
\hline 1987 & 96.81 & 96.01 & 99.80 & 96.27 & 97.36 \\
\hline 1988 & 109.78 & 86.95 & 99.90 & 108.98 & 98.61 \\
\hline 1989 & 104.77 & 77.20 & 99.95 & 104.09 & 93.75 \\
\hline 1990 & 104.17 & 93.10 & 99.55 & 103.49 & 98.72 \\
\hline 1991 & 103.64 & 58.01 & 103.87 & 99.84 & 87.24 \\
\hline 1992 & 102.34 & 105.67 & 103.19 & 101.52 & 103.46 \\
\hline 1993 & 101.87 & 51.01 & 103.48 & 100.91 & 85.13 \\
\hline 1994 & 102.56 & 117.04 & 103.81 & 100.78 & 107.21 \\
\hline 1995 & 103.59 & 167.33 & 104.20 & 100.28 & 123.94 \\
\hline 1996 & 103.93 & 124.43 & 104.65 & 103.62 & 110.90 \\
\hline 1997 & 104.16 & 102.53 & 105.19 & 103.86 & 103.86 \\
\hline 1998 & 103.94 & 86.88 & 105.83 & 102.67 & 98.46 \\
\hline 1999 & 105.10 & 117.88 & 106.61 & 103.25 & 109.25 \\
\hline 2000 & 102.92 & 116.99 & 107.58 & 102.34 & 108.97 \\
\hline 2001 & 103.79 & 99.52 & 109.60 & 106.48 & 105.20 \\
\hline 2002 & 155.58 & 132.41 & 111.27 & 153.15 & 132.28 \\
\hline 2003 & 107.01 & 113.16 & 113.52 & 105.29 & 110.66 \\
\hline 2004 & 106.26 & 129.99 & 116.69 & 106.19 & 117.62 \\
\hline 2005 & 107.07 & 126.79 & 121.50 & 105.74 & 118.01 \\
\hline 2006 & 107.41 & 142.38 & 115.80 & 106.53 & 121.57 \\
\hline 2007 & 107.20 & 109.81 & 120.48 & 106.62 & 112.30 \\
\hline 2008 & 106.27 & 124.78 & 128.36 & 107.73 & 120.29 \\
\hline 2009 & 105.88 & 80.31 & 144.27 & 111.56 & 112.04 \\
\hline 2010 & 105.83 & 125.64 & 122.51 & 104.32 & 124.15 \\
\hline 2011 & 102.92 & 111.31 & 109.13 & 101.47 & 107.30 \\
\hline 2012 & 106.70 & 112.78 & 111.19 & 105.22 & 109.73 \\
\hline 2013 & 102.94 & 111.54 & 114.13 & 104.68 & 110.12 \\
\hline 2014 & 112.72 & 112.28 & 103.59 & 112.72 & 109.53 \\
\hline 2015 & 93.27 & 85.24 & 114.42 & 93.53 & 97.73 \\
\hline 2016 & 68.12 & 84.78 & 102.82 & 68.70 & 85.43 \\
\hline 2017 & 117.87 & 99.70 & 100.67 & 115.78 & 105.39 \\
\hline
\end{tabular}

